\title{
Marine Sponges, Other Animal Food, and Nonfood Items Found in Digestive Tracts of the Herbivorous Marine Turtle Chelonia mydas in Hawai ${ }^{i}{ }^{1}$
}

\author{
Dennis 7. Russell, ${ }^{2,4}$ Stacy Hargrove, ${ }^{3}$ and George H. Balazs ${ }^{3}$
}

\begin{abstract}
Although the usual diet of Chelonia mydas comes from algae and sea grasses (plant material), animal material has been found in samples taken over the past $35 \mathrm{yr}$. The small black-brown protein sponge Chondrosia chucalla resembles the alga Codium arabicum in size, color, and texture, and both grow next to each other on the reefs. We hypothesize that turtles are actively seeking and eating these sponges and not mistaking them for $C$. arabicum. Both protein and silica sponges occur in the diet of Chelonia, but only $6.8 \%$ of the time are eaten in addition to their usual plant diet. Thirty different kinds of other animals were found in the samples, including Cnidaria, Mollusca, Crustacea, Insecta, Echinodermata, squid, fish, tumor flesh, and other animals but in low frequency (5\%). Most of the miscellaneous nonfood debris items were terrestrial leaves, plastic, paper, string, fibers, hair, and paint chips but also in low frequency $(<7 \%)$. Among animal food items known to have nutritional value, the protein sponge C. chucalla could be contributing an important nutritive factor, but this needs further research.
\end{abstract}

The Diet of Chelonia mydas (L.) in Hawai'i usually consists of marine algae and sea grasses, but over the past $35 \mathrm{yr}$ other items have been found in green turtle digestive tracts, especially the black sponge Chondrosia chucalla. Balazs (1980) reported that C. mydas juveniles and adults sometimes feed on invertebrates, such as small anthozoans, Pbysalia, Velella, and Janthina as well as C. chucalla and other sponges. Several other reports have also recorded animal food items, such as Porifera, Coelenterata, Mollusca, Bryozoa, Echinodermata, and Urochordata, in the C. mydas diet

\footnotetext{
${ }^{1}$ Manuscript accepted 15 November 2010.

${ }^{2}$ Department of Biology and Chemistry, American University of Sharjah, P.O. Box 26666, Sharjah, United Arab Emirates (e-mail: drussell@aus.edu).

${ }^{3}$ NOAA, National Marine Fisheries Service, Pacific Islands Fisheries Science Center, 2570 Dole Street, Honolulu, Hawai'i 96822-2396.

${ }^{4}$ Corresponding author.
}

Pacific Science (2011), vol. 65, no. 3:375-381

doi: $10.2984 / 65.3 .375$

(C) 2011 by University of Hawai'i Press

All rights reserved
(Garnett et al. 1985, Meylan 1988, Bjorndal 1990, Fuentes et al. 2006, Arthur and Balazs 2008, Carrion-Cortez et al. 2010). However, Amorocho and Reina (2007) reported that turtles in their study had a bias toward tunicates in addition to algae. It is also well known that $C$. mydas hatchlings are chiefly carnivorous and the larger juveniles and adults are predominantly herbivorous (Thompson 1988, Hirth 1971, 1997). Perhaps some of the early juvenile carnivorous behavior remains in the adults as they eat seaweeds and also prey upon animal material, especially protein sponges that are living in the same reef habitats. In addition, turtles are ingesting other animal food items (Balazs 1985) and nonfood debris with which algae or sponges may be associated. Knowledge of all prey types and availability is essential for the full understanding of every stage of green turtle life history and survival (National Marine Fisheries Service and U.S. Fish and Wildlife Service 2007).

Until recently it was assumed that turtles inadvertently ate C. chucalla while foraging for Codium arabicum, which has an almost identical appearance and texture. Codium arabicum has thalli that are dark green 2-4 cm firm 
lumps growing on hard reef substrate in the same zones and often adjacent to $C$. chucalla. Chondrosia chucalla is a desmosponge that grows as $2-4 \mathrm{~cm}$ stiff black to dark blackbrown lumps on the same coral rock in and among reef algae at shallow depths. Divers have observed both C. mydas and Eretmochelys imbricata actively seeking out and preying upon sponges in deeper cave areas in Hawai' $i$ (Bennett et al. 2008).

Our objectives were to: (1) determine if $C$. mydas is selectively eating C. chucalla and not confusing it with Codium arabicum and (2) classify animal and the miscellaneous nonfood diet items.

\section{MATERIALS AND METHODS}

Diet samples were obtained from stranded turtle necropsies according to the methods described in Russell and Balazs (2009), by stomach lavage (Arthur and Balazs 2008), or directly out of the mouth of the turtle. The greater majority of samples were from the forestomach contents during necropsies (Work 2000). One $50 \mathrm{ml}$ sample was taken from the forestomach of each necropsied turtle, preserved in $10 \%$ formalin/seawater, and analyzed microscopically (Russell and Balazs 2000). The algae were sorted to species, quantified, and converted into percentages, but the animal and debris contents were simply recorded as present/absent and some were measured for size. Correlation between $C$. arabicum and $C$. chucalla was done with the statistical package Minitab 16 (Minitab Inc., State College), where $r=\Sigma(X-\overline{\mathrm{X}})(Y-\overline{\mathrm{Y}}) /$ $S_{x}-S_{y}(X=$ Codium arabicum; $Y=C$. arabicum occurring with $C$. chucalla). Fisher's Exact Test was used to compare percentage results between islands (Rao 1998).

\section{RESULTS AND DISCUSSION}

A total of 2,471 digestive tract samples taken from Chelonia mydas in the six main Hawaiian Islands (Kaua'i, O'ahu, Moloka'i, Maui, Lāna'i, Hawai'i) was examined between 1975 and 2010 (127 mouth, 43 esophagus lavage, 2,201 forestomach, 61 stomach, 39 intestines). The most accurate samples came from the forestomachs, because they gave the greatest amount of fresh and easily identifiable material. The least valuable samples came from fecal pellets, and those are not included in our study because their contents were difficult to identify and many times they were contaminated by feathers, flies, ants, and other things from the environment where they were found.

\section{Chondrosia chucalla and Silica Sponges}

Our original assumption that $C$. mydas was taking $C$. chucalla by mistake while eating $C$. arabicum was unfounded. The desmosponge Chondrosia chucalla was present in 85 of the 2,471 samples, which is an occurrence of about $3.4 \%$. Codium arabicum was present in 376 of the samples, which is about $15 \%$ occurrence, and most of the samples were from O'ahu (Table 1). If the turtles were mistakenly taking $C$. chucalla while grazing on $C$. arabicum there should be a high correlation between these two species and $C$. chucalla should seldom be seen in samples without $C$. arabicum. However, the correlation between C. arabicum together with $C$. chucalla between the six islands is $r=0.203$ and $P=.70$, hence not significant. In addition, $C$. chucalla was most often eaten when $C$. arabicum was not present in the same sample (Table 1). The turtles were not mistaking $C$. chucalla for $C$. arabicum, as was origially assumed, but rather they were eating the sponge on purpose.

Codium arabicum often grows with Codium edule and both contribute significantly to the diets of Chelonia mydas (Russell and Balazs 2009). When all of the sample results were examined for all of the Hawaiian Islands, including the Northwestern Hawaiian Islands (NWHI), 842 samples contained either $C$. arabicum and/or C. edule, and 255 samples $(30 \%)$ contained both at the same time. Turtles graze on both of these common Codium species and could inadvertently graze on $C$. chucalla at the same time. But C. arabicum is distinctly different from $C$. edule, which is a prostrate branching species and does not at all resemble either C. arabicum or C. chucalla in size, shape, or texture.

Chondrosia chucalla was also found without Codium arabicum in 48 of the 85 samples that 
TABLE 1

Codium arabicum, a Green Alga, and Chondrosia chucalla, a Protein Sponge, Found in Digestive Tracts of Chelonia mydas from Six Hawaiian Islands: Numbers of Times Each Was Found in Samples and Numbers of Times $C$. arabicum and C. chucalla Were Found in the Same Samples

\begin{tabular}{lccccccc}
\hline \hline Taxa & Kaua'i & O‘ahu & Moloka'i & Maui & Lāna‘i & Hawaíi & Totals \\
\hline Codium arabicum $^{a}$ & 3 & 348 & 4 & 4 & 7 & 10 & 376 \\
C. arabicum with the sponge C. chucalla & 0 & 36 & 0 & 0 & 1 & 0 & 37 \\
Sponges alone are given below: & & & & & & & \\
Protein sponge Chondrosia chucalla & 2 & 72 & 4 & 2 & 2 & 3 & 85 \\
White silica sponge Spongia oceania & 2 & 12 & 0 & 2 & 1 & 3 & 20 \\
Yellow silica sponge & 1 & 4 & 0 & 0 & 0 & 1 & 5 \\
Orange silica sponge (Mycale armata) & 0 & 2 & 0 & 0 & 0 & 0 & 2 \\
Silica sponge spicules & 3 & 44 & 0 & 4 & 0 & 10 & 61 \\
$\quad$ Total samples with sponges & 8 & 134 & 4 & 8 & 3 & 17 & 174 \\
$\quad$ No. of samples examined & 57 & 1,689 & 63 & 254 & 58 & $350 \%$ & 2,471 \\
$\quad \%$ of samples with sponges & $14 \%$ & $8 \%$ & $6 \%$ & $3 \%$ & $5 \%$ & $5 \%$ & Avg $6.8 \%$ \\
\hline
\end{tabular}

Note: Silica sponges are included for comparison.

a Chlorophyta (green algae).

${ }^{b}$ Unable to identify these sponges to species.

contained the sponge. Chondrosia chucalla, with no C. arabicum present was also found in one sample each from unpublished data we gathered from Saipan, Florida, and Midway and has also been reported from green turtle stomach samples in earlier reports (Balazs 1980, Balazs et al. 1987, Hirth 1997). These additional data also support the hypothesis that $C$. mydas is not inadvertently taking $C$. chucalla along with $C$. arabicum but is actively seeking out and eating this protein sponge.

Glass or hexactinellid sponges contain a myriad of silica spicules that give the sponges a texture similar to fiberglass. Only $88(3.6 \%)$ of the samples contained a few loose silica spicules, which is nearly the same number of times as Chondrosia chucalla. However, when the samples that have only spicules and no recognizable lumps of silica sponge were removed, the percentage of silica sponge appearance in samples dropped to $1 \%$. Hexactinelid sponge species included Spongia oceania (20 samples), Mycale armata (two samples), and a yellow sponge (five samples) that could not be identified to species. Sponges were part of the turtle food ca. $6.8 \%$ of the time, and when sponge data were compared between islands the larger $14 \%$ value from Kaua' $i$ and the $8 \%$ on O'ahu and the percentages at the other islands were not significantly different $(P=.189)$. Therefore, statistically the same amount of sponge was being ingested by $C$. mydas on all of the islands.

Spongivory in Chelonia mydas, Caretta caretta, and Eretmochelys imbricata has been known for a long time (Meylan 1988, Bjorndal 1990) but appears to be of critical importance only in the latter species. Chelonia mydas is primarily an herbivore but consumes a small amount of sponge along with its vegetable diet. We also observed a totally different unidentified small protein sponge species attached to the lower branches of Amansia glomerata (Rhodophyta) in the forestomach samples. Amansia glomerata is a favorite food of $C$. mydas that grows in deeper shaded reef areas rather than on bright shallow reef flats, and this additional protein sponge material may also provide some protein to the turtle diet (Russell and Balazs 2009). Green turtles may also be forced to turn to sponges for food, especially if they cannot find enough algae to sustain themselves. One turtle, not used in our analysis, was artificially confined to a pond in Hawai' $i$, had no algae to eat, and had only silica sponge in its forestomach. We propose that silica sponges, such as Mycale armata, either are not as appealing as the protein sponge Chondrosia chucalla or are eaten when there is no plant material available. 


\section{Animal Food Items in Addition to Sponges}

Other food found in C. mydas samples totaled 28 different kinds of animal items (Table 2), such as small Crustacea (including barnacles) assorted Cnidaria, Echinodermata, Mollusca, worms, invertebrate and fish flesh and bones, eggs, ciliates, insects, turtle skin, and turtle tumor flesh. Sample amounts for each item were low and the results did not lend themselves for accurate statistical analysis. However, $5.6 \%$ of the samples had some kind of animal material in them. Barnacles were found in five of the samples and may have been purposely eaten by the turtles. The Cnidaria (jellyfish and Physalia) were present as withered masses that look like wads of clear cellophane without the jelly but with an abundance of triggered cnidocytes. Balazs (1980) reported both juvenile and subadult green turtles at Midway and Kure (NWHI) "voraciously feeding on Physalia and Velella." Seminoff et al. $(2002,2006)$ and Heithaus et al. (2002) used real-time video-time-depth recorders attached to adult green turtles in Bahía de los Angeles, Mexico, that showed them feeding on Cnidaria (Scyphozoa medusa, Ptilosarcus undulatus, Antipathes galapagensis, and Lytocarpus nuttini) and Annelida, but no sponges were reported in their data. The use of video-time-depth recorders such as those used on green turtles would greatly enhance

TABLE 2

Other Animal Food Items Found in Chelonia mydas Mouth, Esophagus Flush, Forestomach, Stomach, and Intestine Samples

\begin{tabular}{|c|c|c|c|c|c|c|c|}
\hline Type of Animal Material & Kaua'i & O'ahu & Moloka'i & Maui & Lāna‘i & Hawai'i & Totals \\
\hline Crustacea & 0 & 7 & 1 & 1 & 1 & 13 & 23 \\
\hline Copepoda & 0 & 0 & 0 & 0 & 1 & 1 & 2 \\
\hline Isopoda & 0 & 0 & 0 & 0 & 0 & 2 & 2 \\
\hline Decapoda & 0 & 0 & 0 & 2 & 0 & 0 & 2 \\
\hline Shrimp & 0 & 0 & 0 & 1 & 0 & 3 & 4 \\
\hline Barnacles & 0 & 4 & 0 & 0 & 0 & 1 & 5 \\
\hline Arachnida (black mites) & 0 & 2 & 0 & 0 & 0 & 0 & 2 \\
\hline Insecta Periplaneta americana & 0 & 1 & 0 & 0 & 0 & 0 & 1 \\
\hline Bryozoa & 0 & 9 & 0 & 0 & 0 & 1 & 10 \\
\hline Hydrozoa & 3 & 4 & 1 & 1 & 0 & 2 & 11 \\
\hline Cnidaria (jellyfish) & 0 & 3 & 0 & 0 & 0 & 1 & 4 \\
\hline Anemones & 0 & 1 & 0 & 0 & 0 & 0 & 1 \\
\hline Octocorals (soft corals) & 0 & 2 & 0 & 1 & 0 & 3 & 6 \\
\hline Physalia sp. & 0 & 1 & 0 & 0 & 0 & 0 & 1 \\
\hline Echinodermata (small sea cucumbers) & 0 & 0 & 0 & 0 & 0 & 2 & 2 \\
\hline Fish flesh and bones & 0 & 0 & 0 & 1 & 0 & 1 & 1 \\
\hline Flesh (animal muscle) & 1 & 7 & 0 & 1 & 0 & 1 & 10 \\
\hline Mollusca & 1 & 2 & 0 & 0 & 0 & 2 & 2 \\
\hline Brachidontes crebristiatus & 0 & 2 & 0 & 0 & 0 & 0 & 2 \\
\hline Nudibranchs & 0 & 1 & 0 & 0 & 0 & 1 & 2 \\
\hline Snails (micromollusks) & 0 & 1 & 0 & 0 & 0 & 4 & 5 \\
\hline Snail eggs & 7 & 0 & 1 & 0 & 0 & 0 & 1 \\
\hline Squid pens & 0 & 1 & 0 & 0 & 0 & 0 & 1 \\
\hline Platyhelminthes (flukes) & 0 & 5 & 1 & 0 & 0 & 0 & 6 \\
\hline Polychaete worms & 0 & 1 & 0 & 0 & 0 & 1 & 2 \\
\hline Tube worms & 0 & 5 & 0 & 0 & 0 & 2 & 7 \\
\hline Numerous $1 \mathrm{~mm}$ diam. eggs & 0 & 1 & 0 & 0 & 0 & 1 & 2 \\
\hline Stalked ciliates & 0 & 0 & 0 & 0 & 0 & 2 & 2 \\
\hline Turtle skin fragments & 0 & 3 & 0 & 0 & 0 & 0 & 3 \\
\hline Turtle tumor flesh & 1 & 5 & 0 & 0 & 1 & 0 & 7 \\
\hline Total animal food items & 10 & 69 & 4 & 8 & 3 & 43 & 138 \\
\hline$\%$ of 2,471 samples & $0.4 \%$ & $2.8 \%$ & $0.2 \%$ & $0.3 \%$ & $0.1 \%$ & $1.7 \%$ & $5.6 \%$ \\
\hline
\end{tabular}


the understanding of green turtle foraging behavior in Hawai' $i$ (Heithaus et al. 2002, Seminoff et al. 2006).

The Mollusca were mostly small micromollusks that are also commonly found among the algae (the primary food source for Chelonia mydas). Most of the egg masses we found were in jelly and most likely from micromollusks. Animal flesh and squid pens were often found in the same samples, and the squid flesh was recognized by its different texture from fish flesh, which was usually accompanied by fish bones. Hirth (1997) also reported that captive hatchling green turtles would eat sea anemones, shrimp, and fish when it was given to them by their keepers. Turtle skin and tumor flesh were found in 10 forestomach samples and may have come from their own tumors, which can often be located in the mouth (Balazs and Pooley 1991) or from biting tumors off of other turtles.

\section{Miscellaneous Nonfood Items}

Most of the nonfood material found in turtles was terrestrial grass and general kinds of leaves (119 samples at a 9.6\% frequency). Casuarina equisetifolia (ironwood) leaves were identified and occasionally Scaevola sericea (beach naupaka), but grasses were identifiable only to family, because the grass fragments were too deteriorated to allow determination to species. The shoreline where turtles feed is sometimes lined with C. equisetifolia trees and S. sericea shrubs (Balazs et al. 1987). It appears that terrestrial plant leaves and mangrove fruits are part of the usual diet items of green turtles in South America (Carrion-Cortez et al. 2010).

Plastic, paper, string, fibers, human hair, and paint chips were found but to a lesser extent (76 samples at a $3 \%$ frequency). The paint chips were most often blue, orange, or red and could have been ingested along with algae and other food items attached at the waterline of boats or buoys. One unusual sample from Mā'ili Point, O'ahu (13 December 1992), contained masses of American cockroach (Periplaneta americana) fragments, wings, legs, and eggs (Table 2). Perhaps the cockroaches were flushed out of a storm drain and eaten by the turtles as they floated on the surface. Most of the nonfood items were found in the $\mathrm{O}^{\prime}$ ahu and Hawai'i samples and the least from Lāna'i (Table 3). Insects were considered to be a supplemental food item for posthatchling loggerhead turtles feeding in floating patches of Sargassum $93 \mathrm{~km}$ east of

TABLE 3

Miscellaneous Ingested Nonfood Items Found in Chelonia mydas Out of a Total of 2,471 Digestive Tract Samples

\begin{tabular}{lccccccc}
\hline \hline Nonfood Items & Kaua'i & O'ahu & Moloka'i & Maui & Lāna'i & Hawai'i & Totals \\
\hline Terrestrial grass & 2 & 29 & 1 & 2 & 0 & 5 & 39 \\
Terrestrial leaves & 0 & 31 & 0 & 0 & 0 & 19 & 50 \\
Casuarina equisetifolia & 1 & 26 & 0 & 2 & & 1 & 30 \\
Cloth & 0 & 1 & 0 & 0 & 0 & 2 & 3 \\
Cotton fibers & 0 & 2 & 0 & 0 & 0 & 0 & 2 \\
Monofilament line & 0 & 6 & 0 & 0 & 0 & 1 & 7 \\
Paper & 0 & 3 & 0 & 0 & 0 & 0 & 3 \\
String & 0 & 6 & 0 & 0 & 0 & 0 & 6 \\
Synthetic fibers & 0 & 2 & 0 & 0 & 1 & 1 & 4 \\
Plastic hard & 1 & 2 & 0 & 0 & 0 & 0 & 3 \\
Plastic film & 0 & 4 & 1 & 1 & 0 & 0 & 6 \\
Paint chips & 0 & 2 & 0 & 1 & 0 & 0 & 3 \\
Animal hair & 1 & 5 & 0 & 0 & 0 & 0 & 6 \\
Insect parts & 0 & 1 & 0 & 0 & 0 & 0 & 1 \\
Total nonfood items & 5 & 120 & 2 & 6 & 1 & 29 & 163 \\
\% of 2,471 samples & $0.2 \%$ & $4.9 \%$ & $0.08 \%$ & $0.2 \%$ & $0.04 \%$ & $1.2 \%$ & $6.6 \%$ \\
Total no. of samples examined & 57 & 1,689 & 63 & 254 & 58 & 350 & 2,471
\end{tabular}


Florida (Richardson and McGillivary 2001) and for the Kemp's ridley turtle (Dobre 1996). Miscellaneous nonfood items do not appear often enough in the green turtle diet in Hawai' $i$ for us to conclude that they are of any primary importance.

\section{ACKNOWLEDGMENTS}

Acknowledgment is given to Assia Lasfer, who developed the data base; to Lumpai Russell for data entry; and to Hana Sulieman, Mathematics Department, American University of Sharjah, for the statistical analysis. We thank Shawn Murakawa, Bruce Mundy, Shandell Brunson, Thierry Work, Marc Rice, Skippy Hau, Robert Morris, Don Heacock, Donna Brown, Cody Hooven, and numerous other colleagues in the Hawaiian Islands, including the University of Hawai'i Marine Option Program, Hawai'i Preparatory Academy, and Hawaiian Islands Humpback Whale National Marine Sanctuary, for contributing samples.

\section{Literature Cited}

Amorocho, D. F., and R. D. Reina. 2007. Feeding ecology of the East Pacific green turtle Chelonia mydas agassii at Gorgona National Park, Colombia. Endang. Species Res. 3:43-51.

Arthur, K. E., and G. H. Balazs. 2008. A comparison of immature green turtle (Chelonia mydas) diets among seven sites in the Main Hawaiian Islands. Pac. Sci. 62:205-217.

Balazs, G. H. 1980. Synopsis of biological data on the green turtle in the Hawaiian Islands. NOAA Tech. Memo. NOAATM-NMFS-SWFC-7.

- 1985. Impact of ocean debris on marine turtles: Entanglement and ingestion. Pages 387-429 in R. S. Shomura and H. O. Yoshida, eds. Proceedings of the Workshop on the Fate and Impact of Marine Debris, 26-29 November 1984, Honolulu, Hawai'i. NOAA Tech. Memo. NOAATM-NMFS-WWFC-54.

Balazs, G. H., R. G. Forsyth, and A. K. H. Kam. 1987. Preliminary assessment of habitat utilization by Hawaiian green tur- tles in their resident foraging pastures. NOAA Tech. Memo. NOAA TM-NMFSSWFSC-71.

Balazs, G. H., and S. G. Pooley. 1991. Research plan for marine turtle fibropapilloma. NOAA Tech. Memo. NOAA-TMNMFS-SWFC-156.

Bennett, P., U. Keuper-Bennett, and G. H. Balazs. 2008. Changing the landscape: Evidence for detrimental impacts to coral reefs by Hawaiian marine turtles. NOAA Tech. Memo. NOAA-TM-NMFS-SEFSC- 147.

Bjorndal, K. A. 1990. Digestibility of the sponge Chondrilla nucula in the green turtle, Chelonia mydas. Bull. Mar. Sci. 47:567570.

Carrion-Cortez, J. A., P. Zarate, and J. A. Seminoff. 2010. Feeding ecology of the green turtle (Chelonia mydas) in the Galapagos Islands. J. Mar. Biol. Assoc. U.K. 90:1005-1013.

Dobre, J. L. 1996. Lepidochelys kempii (Kemp's Ridley Turtle) feeding on insects. Herpetol. Rev. 27:199.

Fuentes, M. M. P. B., I. R. Lawler, and E. Gyuris. 2006. Dietary preferences of juvenile green turtles (Chelonia mydas) on a tropical reef flat. Wildl. Res. 33:671-678.

Garnett, S. T., I. R. Price, and F. J. Scott. 1985. The diet of the green turtle, Chelonia mydas (L.), in Torres Strait. Aust. Wildl. Res. 12:103-112.

Heithaus, M. R., J. M. McLash, A. Frid, L. M. Dill, and G. J. Marshal. 2002. Novel insights into the behavior of sea turtles from animal-borne cameras. J. Mar. Biol. Assoc. U.K. 82:1049-1050.

Hirth, H. F. 1971. Synopsis of the biological data on the green turtle, Chelonia mydas (Linnaeus) 1758. F.A.O Fish. Synop. No. 85 .

1997. Synopsis of the biological data on the green turtle, Chelonia mydas (Linnaeus 1758). U.S. Fish Wildl. Serv. Biol. Rep. 97 (1).

Meylan, A. B. 1988. Spongivory in hawksbill turtles: A diet of glass. Science (Washington, D.C.) 239:393-395.

National Marine Fisheries Service and U.S. Fish and Wildlife Service. 2007. Green sea turtle (Chelonia mydas) 5-year review: Summary and evaluation. NMFS, Silver Spring, 
Maryland, and USFWS Southeast Region, Jacksonville Ecological Services Field Office, Jacksonville, Florida.

Rao, P. V. 1998. Statistical research methods in the life sciences. Duxbury Press, Pacific Grove, California.

Richardson, J. I., and P. McGillivary. 2001. Post-hatchling loggerhead turtles eat insects in Sargassum community. Mar. Turtle Newsl. 55:2-5.

Russell, D. J., and G. H. Balazs. 2000. Identification manual for dietary vegetation of the Hawaiian green turtle Chelonia mydas. NOAA Tech. Memo. NOAA-TMNMFS-SWFSC-294.

. 2009. Dietary shifts by green turtles (Chelonia mydas) in the Kāne'ohe Bay region of the Hawaiian Islands: A 28-year study. Pac. Sci. 63:181-192.
Seminoff, J. A., T. T. Jones, and G. J. Marshall. 2006. Underwater behavior of green turtles monitored with video-time-depth recorders: What's missing from dive profiles? Mar. Ecol. Prog. Ser. 322:269-280.

Seminoff, J. A., A. Resendiz, and W. J. Nichols. 2002. Diet of East Pacific green turtles (Chelonia mydas) in the central Gulf of California, Mexico. J. Herpetol. 36:447-453.

Thompson, N. B. 1988. The status of loggerhead, Caretta caretta; Kemp's Ridley, Lepidochelys kempi; and green, Chelonia mydas, sea turtles in U.S. waters. Mar. Fish. Rev. $50: 16-23$.

Work, T. M. 2000. Sea turtle necropsy manual for biologists in remote refuges. U.S. Geological Survey National Wildlife Health Center Hawai'i Field Station. 
